\title{
Giant coronary aneurysm presenting as acute coronary syndrome in a patient with systemic lupus erythematosus
}

\author{
Naresh Monigari, ${ }^{1}$ Rohith Reddy Poondru, ${ }^{2}$ Ranjan K Shetty, ${ }^{2}$ Ganapathiraman Vivek ${ }^{2}$
}

1 Department of Medicine, Kasturba Medical College, Manipal, Karnataka, India ${ }^{2}$ Department of Cardiology, Kasturba Medical College, Manipal, Karnataka, India

\section{Correspondence to} Dr Naresh Monigari, medico.ktya@gmail.com

Accepted 12 March 2014
CrossMark

\begin{tabular}{|l|}
\hline To cite: Monigari N, \\
Poondru RR, Shetty RK, \\
et al. BMJ Case Rep \\
Published online: [please \\
include Day Month Year] \\
doi:10.1136/bcr-2014- \\
204009 \\
\hline
\end{tabular}

\section{DESCRIPTION}

We report the case of a 30-year-old woman who presented to the emergency department with rest angina on a background of 3-year history of active systemic lupus erythematosus (SLE) with lupus nephritis on immunosuppressants and steroids. The patient had no evidence of cardiac disease. General examination revealed moderate pallor, whereas systemic examination revealed an early diastolic murmur in the aortic area and bilateral basal crepitations. There were no peripheral signs of aortic regurgitation. The ECG showed ST segment depressions with $\mathrm{T}$ inversions in anterior precordial leads (V1-V6). Echocardiography revealed moderate aortic regurgitation (figure 1) with anterolateral wall hypokinesia and moderate left ventricular systolic dysfunction. Renal parameters were deranged and had a rising titre of troponin $\mathrm{T}$, so a diagnosis of non-ST elevation myocardial infarction was made and anticoagulants were started. Coronary angiography showed a giant coronary artery aneurysm (CAA) arising from the left anterior descending artery (figure 2). In view of the coexisting moderate aortic regurgitation, the patient was advised aortic valve replacement along with coronary artery bypass graft. Also, haemodialysis was initiated in view of the possibility of uraemia causing left ventricular dysfunction with aortic regurgitation and to re-evaluate the condition for surgery after improvement in the general condition. CAAs in SLE are rare. Detection of coronary aneurysms has become more common because of the wide usage of coronary angiography. The incidence of CAAs in SLE is $0.15-4.9 \%$ of the cases undergoing coronary angiography, and giant CAAs are even rarer. ${ }^{1}$ Suzuki et $a l^{1}$ described the association of
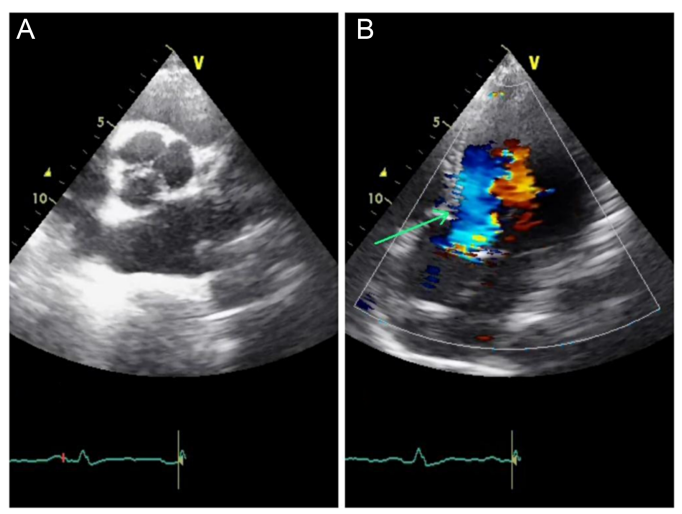

Figure 1 A 2-dimensional-echocardiogram parasternal short axis view showing an aortic valve (A) and aortic regurgitation shown by an arrow on colour Doppler view (B).
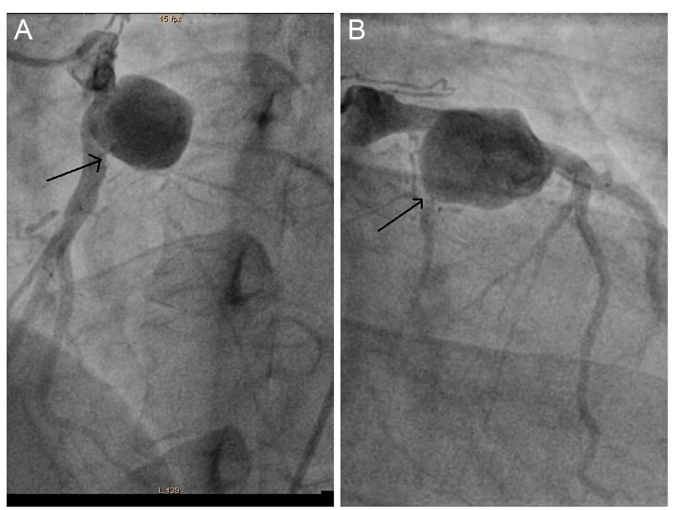

Figure 2 Coronary angiography showing a giant aneurysm of the left anterior descending artery on the right anterior oblique (RAO) cranial (A) and RAO caudal view (B).

CAAs in SLE and emphasised the need for screening in patients with SLE. Coronary aneurysm formation had no correlation with disease activity in SLE as cases were also reported in patients with well-controlled disease. ${ }^{2}$ Deposition of immune aggregates in the walls of coronary vessels ${ }^{3}$ and accelerated atherosclerosis ${ }^{2}$ may be the plausible explanations for formation of CAAs in SLE. In view of the rarity of such lesions, no guidelines were established for their optimal management.

\section{Learning points}

- In view of the increasing evidence of association between systemic lupus erythematosus (SLE) and coronary aneurysms, it may be worthwhile to perform coronary angiography in symptomatic patients to detect lesions at an earlier date so that definitive repair can be carried out, although no definite guidelines have been published.

- Coronary artery aneurysms as a cause of angina have to be suspected even in patients with SLE in clinical remission as there was no strong correlation between SLE activity and coronary arteritis. ${ }^{2}$

Contributors NM participated in the writing of the manuscript and literature review. RRP and GV participated in the review and analysis. Final review before submission was carried out by RKS and NM.

Competing interests None.

Patient consent Obtained. 
Provenance and peer review Not commissioned; externally peer reviewed.

\section{REFERENCES}

1 Suzuki $H$, Fujigaki $Y$, Mori $M$, et al. Giant coronary aneurysm in a patient with systemic lupus erythematosus. Intern Med 2009;48:1407-12.
2 Wilson VE, Eck SL, Bates ER. Evaluation and treatment of acute myocardial infarction complicating systemic lupus erythematosus. Chest 1992;101:

420-4.

3 Korbet SM, Schwartz MM, Lewis EJ. Immune complex deposition and coronary vasculitis in systemic lupus erythematosus. Report of two cases. Am J Med 1984;77:141-6.

Copyright 2014 BMJ Publishing Group. All rights reserved. For permission to reuse any of this content visit http://group.bmj.com/group/rights-licensing/permissions.

BMJ Case Report Fellows may re-use this article for personal use and teaching without any further permission.

Become a Fellow of BMJ Case Reports today and you can:

- Submit as many cases as you like

- Enjoy fast sympathetic peer review and rapid publication of accepted articles

- Access all the published articles

- Re-use any of the published material for personal use and teaching without further permission

For information on Institutional Fellowships contact consortiasales@bmjgroup.com

Visit casereports.bmj.com for more articles like this and to become a Fellow 